\title{
Pengelolaan Bank Sampah "Sampat Sehe Kedas" Desa Selat, Kecamatan Sukasada, Kabupaten Buleleng
}

\author{
Putu Angga Wirawan*1, Lulup Endah Tripalupi \\ 1,2Program Studi Pendidikan Ekonomi \\ Universitas Pendidikan Ganesha \\ Singaraja, Indonesia
}

e-mail: putuanggawirawan33@gmail.com*1, tripalupilulup@gmail.com²

\begin{abstract}
Riwayat Artikel
Tanggal diajukan:

12 Februari 2021

Tanggal diterima : 24 Mei 2021

Tanggal

dipublikasikan:

25 Juni 2021

Abstrak

Tujuan dari penelitian ini untuk mengetahui Pengelolaan Bank Sampah "Sampat Sehe Kedas" Desa Selat, Kecamatan Sukasada, Kabupaten Buleleng. Penelitian ini menggunakan metode penelitian kualitatif. Teknik pengumpulan data dengan metode wawancara dan dokumentasi. Penentuan informan dilakukan dengan purposive. Data yang diperoleh dari hasil wawancara yang dianalisis dengan merekduksi, menyajikan, dan menarik kesimpulan. Hasil penelitian Pengelolaan Bank Sampah "Sampat Sehe Kedas" Desa Selat menunjukkan bahwa perencanaan berjalan dengan baik dilihat dari penetapan tujuan yaitu ingin membantu masyarakat dalam mengelola sampah dengan membentuk organisasi, menyediakan anggaran keuangan, memenuhi perlengkapan dan peralatan, mengidentifikasi masalah, dan mengembangkan rencana dengan musyawarah. Pengorganisasian berjalan dengan baik dilihat dari terbentuknya struktur organisasi. Pengarahan berjalan dengan baik dilihat dari koordinasi antara ketua dan petugas sebelum melaksanakan kegiatan dan saling memberikan motivasi. Pengawasan berjalan dengan baik dilihat dari standar pelaksanaannya pengurus dan petugas sudah berkerja sesuai dengan hari yang disepakati dan sampah yang ditabung nasabah sampah non organik dengan harga perkilo $\operatorname{Rp} 500,00$.
\end{abstract}

Kata kunci : pengelolaan; bank sampah; sampat sehe kedas

Pengutipan:

Wirawan, P. A. \&

Tripalupi, L. E. (2021).

Pengelolaan Bank Sampah "Sampat Sehe Kedas" Desa Selat, Kecamatan Sukasada, Kabupaten Buleleng. Jurnal Pendidikan Ekonomi Undiksha, 13(1), 126-135 http://dx.doi.org/1 $0.23887 / j$ jpe.v13i 1.32103

\section{Abstract}

The purpose of this study was to determine the management of the "Sampat Sehe Kedas" Waste Bank in Selat Village, Sukasada District, Buleleng Regency. This research uses qualitative research methods. Data collection techniques using interview and documentation methods. The determination of informants was done purposively. The data obtained from the interviews were analyzed by producing, presenting, and drawing conclusions. The results of the research on the Management of the Sampat Sehe Kedas Waste Bank in Selat Village show that planning is going well in terms of goal setting, namely wanting to help the community in managing waste by forming an organization, providing a financial budget, fulfilling equipment and equipment, identifying problems, and developing plans by deliberation. Organizing goes well in terms of the formation of the organizational structure. The briefing went well, seen from the coordination between the chairman and officers before carrying out activities and giving each other motivation. Supervision runs well, seen from the standard of implementation, the management and officers have worked according to the agreed day and the waste that customers save is non-organic waste at a price of Rp. 500.00/ kg

Keywords: management; sampat sehe kedas; waste bank 


\section{PENDAHULUAN}

Sampah merupakan permasalahan yang pelik, karena setiap hari semakin menumpuk. Pemerintah berusaha mengatasi permasalahan sampah dengan mengolah sampah secara terpadu yaitu mengurangi sampah dengan melakukan pemanfaatan kembali sampah yang masih bisa digunakan, melakukan daur ulang, dan dijadikan pupuk. Menurut Hadiwiyoto (1983) jika ditinjau dari segi keseimbangan lingkungan, kesehatan, keamanan, dan pencemaran, apabila sampah tidak dikelola dengan baik dapat menimbulkan berbagai gangguan-gangguan antara lain, pencemaran udara, pencemaran air, dan pencemaran tanah. Menurut Peraturan Menteri Negara Lingkungan Hidup RI Nomor 13 Tahun 2012 Tentang Pedoman Pelaksanaan Bank Sampah, bank sampah di atur dalam pasal 1 ayat 2 peraturan ini. Adapun bunyi pasal ini yaitu "bank sampah adalah tempat pemilahan dan pengumpulan sampah yang dapat diaur ulang dan di guna ulang yang memiliki nilai ekonomi".

Bank Sampah "Sampat Sehe Kedas" terletak di Desa Selat, Kecamatan Sukasada, Kabupaten Buleleng, tepatnya di Banjar Dinas Witajati. Bank Sampah ini dibentuk oleh muda mudi Banjar Dinas Witajati pada tanggal 04 Januari 2014 dengan anggota berjumlah 27 orang. Berdirinya bank sampah ini karena masih banyak masyarakat Desa Selat membuang sampah tidak pada tempatnya seperti di sungai dan ada yang dibakar sehingga menyebabkan lingkungan menjadi kotor, timbulnya berbagai macam penyakit, pencemaran lingkungan dan rusaknya ekosistem. Adanya bank sampah "Sampat Sehe Kedas" sangat membantu masyarakat Desa Selat dalam pengelolaan sampah sehingga tidak lagi dibuang di sembarang tempat atau dibakar saja. Masyarakat dapat memilah terlebih dahulu sampah-sampah yang akan dikumpulkan kepada bank sampah "Sampat Sehe Kedas". Anggota bank sampah "Sampat Sehe Kedas" nantinya akan berkeliling mengambil sampah-sampah yang telah dikumpulkan ke rumah-rumah masyarakat. Setiap pengambilan sampah akan ditimbang berat sampahnya terlebih dahulu, setelah itu akan dicatat dan akan diberikan kartu anggota serta buku tabungan untuk menyimpan hasil dari pengumpulan sampah-sampah tersebut. Harga per kilo dari sampah-sampah tersebut dihargai sebesar Rp.500. Sampah-sampah yang telah dikumpulkan akan dijual kembali oleh anggota bank sampah kepada pengepul. Hasil penjualan sampah tersebut akan dibayarkan kepada anggota bank sampah "Sampat Sehe Kedas" sesuai dengan saldo tabungan yang dimiliki dan sisanya akan dimasukkan ke khas bank sampah "Sampat Sehe kedas". Pengambilan uang tabungan tersebut dapat dilakukan satu bulan sekali.

Bank sampah lahir dari program Jakarta Green and Clean yaitu salah satu cara pengelolaan sampah skala rumah tangga, yang menitik beratkan pada pemberdayaan masyarakat dalam mengelola sampah rumah tangga. Bank sampah adalah tempat menabung sampah yang telah terpilih menurut jenis sampah dan yang mempunyai nilai ekonomis. Cara kerja bank sampah pada umumnya hampir sama dengan bank lainnya, ada nasabah, pencatatan pembukuan dan manajemen pengelolaannya, apabila dalam bank yang biasa kita kenal yang disetorkan nasabah adalah uang akan tetapi dalam bank sampah yang disetorkan adalah sampah yang mempunyai nilai ekonomis, sedangkan pengelola bank sampah harus orang kreatif dan inovatif serta memiliki jiwa kewirausahaan agar dapat meningkatkan pendapatan masyarakat. Sistem kerja bank sampah pengelolaan sampahnya berbasis rumah tangga, dengan memberikan reward kepada yang berhasil memilah dan menyetorkan sejumlah sampah.

Konsep bank sampah membuat masyarakat sadar bahwa sampah memiliki nilai jual yang dapat menghasilkan uang, sehingga mereka peduli untuk mengelolanya, mulai dari pemilahan, pengomposan, hingga menjadikan sampah sebagai barang yang bisa digunakan kembali dan bernilai ekonomis. Bank sampah ini menjadi salah satu solusi bagi pengelolaan sampah di Indonesia yang masih bertumpu pada pendekatan akhir. Dengan program ini, sampah mulai dikelola dari awal sumber timbunan sampah, yaitu 
rumah tangga. Cara menabung pada bank sampah dilakukan dengan cara setiap nasabah mendaftar kepada pengelola, pengelola akan mencatat nama nasabah dan setiap calon anggota akan diberi buku tabungan secara resmi. Bagi nasabah yang ingin menabung sampah, caranya cukup mudah, tinggal datang ke kantor bank sampah dengan membawa sampah, sampah yang akan ditabung harus sudah dipilah-pilah sesuai dengan jenisnya seperti kertas, plastik, botol, kaleng, besi, alumunium dan lainnya dimasukkan kekantong-kantong yang terpisah.

Menurut Arikunto

"pengelolaan dapat disamakan dengan manajemen, yang berarti pula pengaturan atau pengurusan. Pengelolaan diartikan sebagai suatu rangkaian pekerjaan atau usaha yang dilakukan oleh sekelompok orang untuk melakukan serangkaian kerja dalam mencapai tujuan tertentu. Follet, (1997) mendefinisikan pengelolaan adalah seni atau proses dalam menyelesaikan sesuatu yang terkait dengan pecapaian tujuan. Menurut Fattah (2004) "bahwa dalam proses manajemen terlibat fungsifungsi pokok yang ditampilkan oleh seorang manajer atau pimpinan, yaitu perencanaan (planning), pengorganisasian (organising), pemimpin (leading), dan pengawasan (controlling)"

Menurut Bucher \& Krotee (2004)) manajemen adalah proses perencanaan, pengoranisasian, pengarahan, dan pengendalian usaha para anggota organisasi dan penggunaan sumber daya organiasi lainnya untuk mencapai tujuan. Perencanaan merupakan proses dasar dari suatu kegiatan pengelolaan dan merupakan syarat mutlak dalam suatu kegiatan pengelolaan. Burhanudin (1994) mendefinisikan perencanaan sebagai berikut: "perencanaan merupakan suatu proses kegiatan pemikiran yang sistematis mengenai apa yang akan dicapai, kegiatan yang harus dilakukan, langkah-langkah, metode, dan tenaga yang dibutuhkan untuk menyelenggarakan kegiatan pencapaian tujuan yang dirumuskan secara rasional dan logis serta berorientasi kedepan dan masa kini". Perencanaan dapat diartikan upaya merumuskan arah masa depan organisasi, menetapkan sasaran dan cara- cara untuk mencapai sasaran itu (Amir, 2006).

Pengorganisasian adalah proses terciptanya penggunaan secara tertib terhadap semua sumber daya yang dimiliki oleh sistem manajemen. Pengorganisasian merupakan proses penyusunan struktur organisasi yang sesuai dengan tujuan organisasi sumber daya sumber daya yang dimilikinya dan lingkungan yang melingkupinya, (T. Hani, 2000). Setiap pengorganisasian harus memiliki struktur organisasi yang layak. Struktur organisasi dicerminkan dalam bentuk bagan atau grafis yang disebut dengan bagan organisasi. Menurut Michael (2002)) "fungsi pengorganisasian memiliki peranan yang sangat penting dalam sistem manajemen, dikarenakan proses pengorganisasian merupakan mekanisme utama yang dipergunakan oleh para manajer untuk menggerakkan rencana yang telah disusun". Organisasi merupakan wadah di mana berlangsung proses-proses pengorganisasian sumber daya sumber daya organisasi.

Pengarahan adalah suatu kemampuan untuk dapat mempengaruhi orang lain agar dapat melalukan suatu kegiatan. Menurut Siswanto (2005) "pengarahan adalah suatu kegiatan yang berhubungan dengan pemberian perintah dan saran". Amir (2006) mengemukakan bahwa "pengarahan (directing) adalah membuat pegawai mengerjakan apa yang seharusnya dikerjakan dan memotivasinya untuk mencapai tujuan organisasi, ada yang mengatur, mengarahkan, memotivasi, memberikan sangsi dan lainlain". Pimpinan atau manajer perlu mengarahkan, perlu mendorong dengan memberikan tuntunan agar pegawai mengerjakan dengan usaha dan cara yang sesuai dengan keinginan organisasi. Manajer atau pimpinan organisasi harus memiliki cara tertentu muncul keinginan dari bawahan untuk mengikuti manajer atau pimpinan organisasi. Pimpinan harus punya kekuasaan, sifat dan karakter tertentu, gaya yang disesuaikan dengan situasi organisasi dan karakter pegawai dalam mengarahkan dan mendorong itu. Menurut Garry K (2004) yang dimaksud dengan "kepemimpinan adalah proses 
dimana seorang individu mempunyai pengaruh terhadap orang lain dan mengilhami, memberi semangat, memotivasi, dan mengarahkan kegiatankegiatan mereka guna membantu tercapainya tujuan kelompok dan organisasi".

"Pengawasan adalah kegiatan membandingkan atau mengukur yang sedang atau sudah dilaksanakan dengan kriteria, norma-norma standar atau rencana-rencana yang sudah ditetapkan sebelumnya" (Sutarno, 2004). Dengan demikian, perencanaan merupakan proses awal dari suatu kegiatan pengelolaan yang keberadaanya sangat diperlukan dalam memberikan arah atau patokan dalam suatu kegiatan, kemudian pengorganisasian berkaitan dengan penyatuan seluruh sumber daya yang ada untuk bersinergi dalam mempersiapkan pelaksanaan kegiatan. Tahap berikutnya pengarahan dan pelaksanaan kegiatan yang selalu berpedoman pada perencanaan yang telah ditetapkan.Tahap terakhir adalah pengawasan yang meliputi kegiatan monitoring dan evaluasi tersebut, dapat dilakukan perbaikan selama kegiatan berlangsung atau untuk memperbaiki program kegiatan berikutnya sehingga tujuan yang telah direncanakan tercapai dengan baik.

Berdasarkan latar belakang yang telah diuraikan di atas, maka penulis tertarik untuk mengadakan penelitian dengan judul Pengeloaan Bank Sampah "Sampat Sehe Kedas" Desa Selat, Kecamatan Sukasada, Kabupaten Buleleng.

\section{METODE}

Penelitian ini merupakan jenis penelitian metode kualitatif, yaitu penelitian yang berlandaskan pada fisafat postposivivisme dimana kebenaran sesuai hakikat, obyek, digunakan untuk meneliti pada kondisi objek yang alamiah, di mana peneliti sebagai instrument kunci dan hasil penelitian lebih menekankan makna dari pada generalisasi. Penelitian ini bermaksud untuk menggungkap data dan infomasi sebanyak mungkin tentang pengelolaan Bank Sampah Sampat Sehe Kedas Desa Selat. Penelitian ini tidak diarahkan pada kesimpulan salah-benar, tidak menguji suatu hipotesis diterimaditolak, tetapi lebih ditekankan pada pengumpulan data untuk mendeskripsikan keadaan sesungguhnya yang terjadi dilapangan secara mendalam.

Lokasi penelitian merupakan tempat dimana peneliti melakukan penelitian untuk mendapatkan peristiwa yang sebenarnya terjadi dari objek yang diteliti dalam rangka mendapatkan data-data penelitian yang akurat. Menurut Nasution, (2003) (Nasution, 2003)“lokasi penelitian menunjukkan pada pengertian tempat atau lokasi sosial penelitian yang dicirikan oleh adanya unsur yaitu, tempat, dan kegiatan yang dapat di observasi. Lokasi penelitian ini di laksanakan di Tempat Bank Sampah "Sampat Sehe Kedas" Desa Selat yang lokasinya di Banjar Witajati.

Sumber data yang digunakan dalam penelitian ini adalah data primer dan data sekunder. Data primer merupakan data yang didapatkan dari sumber langsung. Data primer adalah data yang langsung memberikan data kepada pengumpul data. Data primer di peroleh dari hasil wawancara dengan pengelola Bank Sampah "Sampat Sehe Kedas" Desa Selat. Data sekunder merupakan data yang didapatkan melalui hasil dokumentasi atau melalui orang lain.. Data sekunder penelitian ini adalah daftar organisasi Bank Sampah "Sampat Sehe Kedas" Desa Selat (Sugiyono, 2015).

Informan dalam penelitian ini adalah seluruh pengurus Bank Sampah "Sampat Sehe Kedas" Desa Selat beserta petugas dari bank sampah itu sendiri. Penentuan informan menggunakan metode purposive sampling yaitu memilih sampel dengan kriteria tertentu, sehingga pemilihan sampel tersebut dapat mewakili populasinya yang memenuhi kriteria peneliti. Kriteria yang digunakan dalam 
pemilihan informan adalah orang-orang yang benar-benar memahami pengelolaan Bank Sampah "Sampat Sehe Kedas" Desa Selat. Informan kunci dalam penelitian adalah ketua, bendahara, dan sekertaris dari Bank Sampah "Sampat Sehe Kedas" Desa Selat dan informan tambahannya adalah petugas Bank Sampah "Sampat Sehe Kedas" Desa Selat yang mengetahui pengelolan bank sampah. Jumlah informan yang digunkan dalam penelitian ini adalah 5 orang yang terdiri dari 3 orang pengurus bank sampah dan 2 orang petugas bank sampah yang bersedia di wawancarai serta tahu mengenai pengelolaan Bank Sampah "Sampat Sehe Kedas" Desa Selat.

Metode pengumpulan data yang digunakan dalam penelitian ini wawancara dan dokumentasi. Wawancara dalam penelitian ini dilakukan untuk memperkuat dan memperjelas data yang diperoleh yaitu data tentang bagaimana perencanaan, pengorganisasian, pengarahan, dan pengawasan di Bank Sampah "Sampat Sehe Kedas" Desa Selat. Wawancara dilakukan dengan informan peneliti yaitu ketua, bendahara, sekertaris, dan petugas Bank Sampah "Sampat Sehe Kedas" Desa Selat. Dokumentasi dalam penelitian untuk mendapatkan daftar organisasi dari bank sampah "Sampat Sehe Kedas".

Teknik analisis data adalah proses pengumpulan data secara sistematis untuk mempermudah peneliti dalam memperoleh kesimpulan. Analisis data dalam penelitian ini menggunakan teknik analisis data dalam situs yang dikembangkan oleh Miles Huberman. Data yang sudah terkumpul dibuat dalam matriks. Dalam matriks akan disajikan penggalan-penggalan data deskriptif sekitar peristiwa atau pengalaman tertentu yang menyekat data sebelum dan sesudahnya. Setelah data dimasukkan kedalam matriks selanjutnya di buat daftar cek (Miles \& Amichael, 2007). Analisis data dalam penelitian kualitatif dilakukan sejak sebelum memasuki lapangan, selama memasuki lapangan, dan setelah selesai dari lapangan. Untuk menyajikan data agar mudah dipahami, maka langkah-langkah analisis data yang digunakan dalam penelitian ini adalah analysis interative Model dari Miles dan Huberman, yang membagi langkahlangkah dalam kegiatan analisis data dengan beberapa bagaian yaitu pengumpulan data (data collection), reduksi data (data reduction), penyajian data (data display), dan penarikan kesimpulan atau verifikasi (conclutions).

\section{HASIL DAN PEMBAHASAN}

Hasil

Bank Sampah "Sampat Sehe Kedas" Desa Selat telah mempunyai petugas yang akan mengambil sampah ke anggota atau nasabah bank sampah. Jenis sampah yang di setorkan ke petugas yaitu sampah non organik atau sampah yang mempunyai nilai ekonomis. Sampah yang di setorkan ke petugas akan di timbang terlebih dahulu sebelum sampah diangkut dan harga perkilo sampah yang dijula senilai $\mathrm{Rp}$ 500,00 . Selanjutnya petugas bank sampah akan mengumpulkan sampah ke tempat Bank Sampah "Sampat Sehe Kedas" Desa Selat, setelah pengumpulan sampah dilakukan selanjutnya petugas akan menjual kembali sampah tersebut ke pengepul.

Pengelolaan Bank Sampah "Sampat Sehe Kedas" Desa Selat yang dilakukan dapat memberikan dampak positif bagi masyarakat Desa Selat dalam meningkatkan perekonomiannya dengan cara menabung di bank sampah dan menciptakan lingkungan yang bersih bebas dari sampah organik maupun sampah non organik. Proses Pengelolaan Bank Sampah "Sampat Sehe Kedas" Desa Selat dimulai dari empat fungsi manajemen yaitu perencanaan, pengorganisasian, pengarahan, dan pengawasan.

Bedasarkan hasil wawancara dengan ketua Bank Sampah "Sampat Sehe Kedas" Desa Selat, dapat diuraikan bahwa dari segi perencanaan bank sampah "Sampat Sehe Kedas" Desa Selat mempunyai tahapan-tahapan yang harus dibuat agar perencanaannya berjalan dengan baik. Berikut adalah hasil wawancara dengan Ketua bank sampah mengenai tahapan 
perencanaan Bank Sampah "Sampat Sehe Kedas" Desa Selat.

a. Penetapan tujuan dari adanya Bank Sampah "Sampat Sehe Kedas" Desa Selat untuk membantu masyarakat dalam mengelola sampah agar menjadi barang yang bernilai ekonomis dan untuk mengurangi pencemaran lingkungan agar Desa Selat menjadi desa yang bersih dan bebas dari polusi.

b. Merumuskan keadaan dilakukan untuk menganalisa tujuan dari Bank Sampah "Sampat Sehe Kedas" Desa Selat apa yang perlu dilakukan agar tujuan tersebut dapat berjalan dengan efektif. Upaya dari perumusan kedaan di Bank Sampah Sampat "Sehe Kedas Desa" Selat ini yaitu Pembetukan Organisasi, Pemenuhan SDM, dan menyediakan pelengkapan dan peralatan yang dapat digunakan dalam kegiatan pengambilan sampah.

c. Mengidentifikasi kendala/masalah yaitu proses mengidentifikasi kendalakendala yang di temui selama kegitan Bank Sampah "Sampat Sehe Kedas" Desa Selat. Kendala-kendala yang sering di temui saat pengambilan sampah. Kurangnya petugas pengambilan sampah menjadi masalah utama di Bank Sampah "Sampat Sehe Kedas" Desa Selat hal ini dilihat dari luasnya wilayah Desa Selat yang mencakup dari 7 Banjar Dinas dengan jumlah petugas yang tidak memadai maka akan menghambat pelaksanaan pengambilan sampah, maka upaya yang dilakukan Bank Sampah "Sampat Sehe Kedas" Desa Selat untuk mengatasi masalah tersebut adalah dengan melakukan pengecekan terlebih dahulu ke Banjar-Banjar Dinas untuk mengetahui banjar dinas yang sudah siap untuk diambil sampahnya. Selain kendala kekurangan petugas yang mengambil sampah, kendala lain yang juga ditemui yaitu masalah pengangkutan sampah karena di Bank Sampah "Sampat Sehe Kedas" Desa Selat tidak mempunyai mobil untuk mengangkut sampah, untuk mengatasi masalah tersebut maka hal yang dilakukan oleh ketua selaku penanggung jawab adalah penyewaan mobil pik up.

d. Mengembangkan rencana di Bank Sampah "Sampat Sehe Kedas" Desa Selat dengan melakukan musyawarah. Musyarawah ini dilakukan 6 bulan sekali untuk membahas rencana yang akan digunakan 6 bulan kedepannya supaya kegiatan di Bank Sampah "Sampat Sehe Kedas" Desa Selat dapat berjalan lebih baik dari sebelumnya.

Berdasarkan hasil wawancara dengan Sekretaris Bank Sampah "Sampat Sehe Kedas" Desa Selat dalam proses pengorganisasian langkah yang dilakukan agar tercapainya tujuan yang direncanakan adalah membentuk stuktur organisasi, memberikan pembagian tugas, dan memberikan wewenang kesetiap pengurus dan petugas untuk menyelesaikan tugas yang diberikan. Stuktur organisasi di Bank Sampah "Sampat Sehe Kedas" terdiri dari Penasehat, Ketua, Sekertaris, Bendahara dan Petugas. Stuktur yang ada di Bank Sampah "Sampat Sehe Kedas" Desa Selat sudah disepakati oleh semua anggota bank sampah.

Dalam pembagian tugas di dalam organisasi bank sampah yaitu ada penasehat yang bertugas sebagai penasehat dan pengawas selama kegiatan Bank Sampah "Sampat Sehe Kedas" berjalan. Ketua Bank Sampah "Sampat Sehe Kedas" yang bertugas mengkoordinasikan dan juga megawasi kegiatan-kegiatan yang dilakukan oleh Bank Sampah "Sampat Sehe Kedas". Sekertaris Bank Sampah "Sampat Sehe Kedas" yang bertugas sebagai administrasi atau pencatatan pembukuan yang ada di dalam Bank Sampah "Sampat Sehe Kedas. Bendahara Bank Sampah "Sampat Sehe Kedas" yang bertugas sebagai pencatatan keuangan yang ada didalam bank sampah, dan petugas Bank Sampah "Sampat Sehe kedas" yang bertugas mengambil dan mengumpulkan sampah. Dalam organisasi di bank sampah "Sampat Sehe Kedas" Desa Selat setiap anggota yang ikut di dalam organisasi mempunyai tanggung jawab untuk menyelesasikan tugas yang 
sudah diberikan. Supaya tujuan dari berdirinya Bank Sampah "Sampat Sehe Kedas" Desa Selat yang ingin membantu masyarakat Desa Selat dalam mengelola sampah menjadi barang bernilai ekonomis dan menciptakan Desa Selat yang bersih bebas dari polusi dapat dilaksanakan dengan baik.

Bedasarkan hasil wawancara dengan Ketua bank sampah "Sampat Sehe Kedas" Desa Selat sebelum kegiatan bank sampah dilakukan maka akan di berikan arahan kepada petugas atau pengurus Bank Sampah "Sampat Sehe Kedas" Desa Selat. Hal ini dilakukan supaya pengurus dan petugas Bank Sampah "Sampat Sehe Kedas" dapat bekerja sesuai dengan tugas yang di berikan untuk mencapai keberhasilan dalam tujuan yang direncanakan. Bentuk pengarahan yang diberikan kepada pengurus dan petugas di Bank Sampah "Sampat Sehe Kedas" Desa Selat yaitu Kordinasi, Motivasi dan Komunikasi.

Dari hasil wawancara dengan salah satu petugas Bank Sampah "Sampat Sehe Kedas" Desa Selat bahwa sebelum kegiatan pengambilan sampah dilakukan maka terlebih dahulu petugas akan berkordinasi dengan ketua bank sampah untuk mendapatkan arahan-arahan kemana saja akan dilakukan pengambilan sampahnya dan apa saja peralatan yang perlu disiapkan. Setelah mendapatkan arahan dari ketua bank sampah petugas sudah mengetahui wilayah mana yang akan dituju untuk pengambilan sampahnya. Ketua memberikan motivasi ke pengurus dan petugas untuk menambah semangat dalam mengerjakan tugas yang diberikan. Selain itu, motivasi juga diberikan kepada nasabah Bank Sampah "Sampat Sehe Kedas" Desa Selat untuk meningkatkan kesadaran masyarakat akan pentingnya kebersihan lingkungan dari sampah dan polusi. Komunikasi di Bank Sampah "Sampat Sehe Kedas" Desa Selat dapat dikatakan cukup baik hal ini dilihat dari keterbukaan antara pengurus dan petugas selama kegiatan di bank sampah berlangsung. Dalam penyampaian laporan keuangan dilakukan secara keterbukaan ke semua anggota organisasi di bank sampah, kendala yang ditemui selama kegiatan pengurus maupun petugas selalu melaporkan ke ketua bank sampah, dan menyelesasikan masalah yang ada di bank sampah dengan melakukan musyarwarah.

Berdasarkan hasil wawancara dengan ketua Bank Sampah cara pengawasan di Bank Sampah "Sampat Sehe Kedas" pertama akan dilihat dari standar pelaksanaan. Standar pelaksanaan di Bank Sampah "Sampat Sehe Kedas" yaitu kegiatan pengambilan sampah di setiap nasabah dikerjakan pada hari minggu yang dikerjakan oleh petugas, harga setiap sampah perkilonya Rp 500,00 dan sampah yang dapat ditabung oleh nasabah adalah sampah yang memilki nilai ekonomis seperti sampah plastik, botol dan lainya. Selama berjalannya kegiatan pengambilan sampah petugas bank sampah sudah berjalan sesuai dengan standar pelaksanaan yang ditetapkan di Bank Sampah "Sampat Sehe Kedas" Desa Selat. Selain standar pelaksanaan pengawas juga melihat kinerja petugas dari pengukuran kerjanya, apakah petugas Bank Sampah "Sampat Sehe Kedas" Desa Selat sudah bekerja dengan sungguhsungguh dilihat dari kehadiran pengurus dan petugas disetiap kegiatan, petugas dan pengurus harus datang tepat waktu disetiap kegiatan, petugas pengambilan sampah ke nasabah sudah bekerja dengan arahan wilayah yang sudah ditentukan dan tidak ada nasabah yang ketinggalan dalam pengumpulan sampahnya.

Dalam pengawasan di Bank Sampah "Sampat Sehe Kedas" Desa Selat tindakan koreksi dilakukan untuk tidak terjadinya ketidaksesuaian pelaksanaan selama kegiatan yang berjalan, seperti ketidak hadiran petugas atau pengurus selama kegitan di dalam Bank Sampah "Sampat Sehe Kedas" Desa Selat, minat nasabah menabung di Bank Sampah "Sampat Sehe Kedas" menjadi menurun, hal ini perlu dikoreksi oleh pengawas apa yang menyebab terjadinya masalah-masalah tersebut dan apa yang harus dilakukan oleh pengurus untuk mengatasi masalah tersebut.

\section{Pembahasan}

Perencanaan di Bank Sampah "Sampat Sehe Kedas" Desa Selat 
mempunyai tahapan-tahapan yang dilakukan untuk memperlancar kegiatan di bank sampah seperti penetapan tujuan, merumuskan keadaan, mengidentifikasi masalah, dan mengembangkan rencana. Tahap pertama perencanaan yaitu menentukan tujuan yang ingin membantu masyarakat desa selat dalam mengelola sampah rumah tangga menjadi barang yang bernilai ekonomis dan menjadikan lingkungan Desa Selat menjadi desa yang bersih. Tahap kedua bagaimana upaya bank sampah agar tujuan tersebut dapat berjalan yaitu dengan merumuskan keadaan dari tujuan yang di rencanakan seperti pembentukan organisasi, penyediaan anggaran keuangan, mencari nasabah dan memenuhi pelengkapan dan peralatan yang perlu digunakan untuk pelaksanaan pengambilan sampah.

Tahap ketiga dari perencanaan yaitu mengidentifikasi kendala-kendala yang akan ditemui selama kegiatan bank sampah, kendala yang sering di hadapi di Bank Sampah "Sampat Sehe Kedas" Desa Selat adalah kurangnya petugas dalam pengambilan sampah, dikarena wilayah desa selat yang mencakup 7 banjar dengan jumlah petugas yang tidak memadai maka kegiatan pengambilan sampah kenasabah menjadi tidak efektif. Tahap mengembangkan rencana di Bank Sampah "Sampat Sehe Kedas" Desa Selat yaitu dengan musyawarah yang di lakukan setiap 6 bulan. Dalam musyawarah akan membahas rencana yang akan digunakan 6 bulan kedepannya supaya kegiatan di Bank Sampah "Sampat Sehe Kedas" Desa Selat dapat berjalan lebih baik dari sebelunya.

Pengorganisasian di Bank Sampah "Sampat Sehe Kedas" Desa Selat yaitu mengumpulkan orang-orang yang akan melaksanakan kegiatan untuk mencapai tujuan yang ingin membantu masyarakat Desa Selat dalm mengelola sampahnya dan menciptakan Desa Selat yang bersih dari sampah seperti pembentukan organisasi, pembagian tugas dan memberikan wewenang kesetiap petugas untuk menyelesaikan tugas yag diberikan. Stuktur organisasi yang ada di Bank Sampah "Sampat Sehe Kedas" Desa Selat yaitu Penasehat, Ketua, Sekertaris,
Bendahara, dan Petugas pengambilan sampah.

Setiap anggota yang ada di organisasi Bank Sampah "Sampat Sehe Kedas" Desa Selat sudah memiliki tugasnya masing-masing sesuai dengan yang disepakati oleh pengurus bank sampah, yaitu ada penasehat yang selaku penanggung jawab selama kegiatan bank sampah Bank Sampah "Sampat Sehe Kedas" Desa Selat berjalan. Ketua yang bertugas sebagai pengawas dan pemimpin dalam setiap kegiatan, sekertaris bertugas melakukan pencatakan pembukuan, Bendaraha bertugas sebagai pencatatan keuangan, dan Petugas yang bertugas sebagai tenaga pengambilan sampah ke nasabah Bank Sampah "Sampat Sehe Kedas" Desa Selat. Setiap pengurus dan petugas mempunyai tanggung untuk mengerjakan tugas yang diberikan.

Pengarahan di Bank Sampah "Sampat Sehe Kedas" Desa Selat adalah proses pemberian Kordinasi, Motivasi dan Komunikasi yang baik supaya pelaksanaan yang dilakukan bisa dikerjakan dengan penuh semangat dan memiliki arah tujuan yang jelas. Kordinasi diberikan oleh ketua kesetiap pengurus dan petugas sebelum melakukan kegitan pengambilan sampah maupun kegiatan-kegiatan lainya. Tujuan dari kordinasi supaya pelaksanaan kegiatan yang ada di Bank Sampah "Sampat Sehe Kedas" Desa Selat menjadi terarah sesuai dengan standar pelaksanaan yang di sepakati, tahap kedua yaitu ketua memberikan motivasi di Bank Sampah "Sampat Sehe Kedas" Desa Selat untuk membangkitkan semangat kerja petugas dan pengurus, motivasi juga diberikan ke nasabah bank sampah tujuannya untuk menyadarkan masyarakat betapa pentingnya kebersihan lingkungan untuk menjaga kesehatan. Komunikasi di Bank Sampah "Sampat Sehe Kedas" Desa Selat dari pelaksanaan kegiatan pengumpulan sampah yang di kerjakan secara bersama-sama, untuk memecahkan masalah di bank sampah dengan sistem musyawarah.

Pengawasan di Bank Sampah "Sampat Sehe Kedas" Desa Selat dilakukan oleh Kelian Banjar Witajati selaku Penasehat dan Ketua Bank Sampah dalam 
pengawasan hal yang dinilai adalah standar pelaksanaan. Standar pelaksanaan di Bank Sampah "Sampat She Kedas" Desa Selat yaitu sampah yang bisa ditabung adalah sampah non organik atau sampah yang bisa didaur ulang, harga sampah yang ditabung per kilo Rp 500,00 dan pelaksanaan pengambilan sampah dilakukan setiap hari minggu. Selain dilihat dari standar pelaksanaan pengukuran kinerja juga dilakukan dalam pengawasan, hal ini untuk menilai keseriusan pengurus dan petugas bank sampah dalam mengerjakan tugasnya, harus sesuai dengan arahan-arahan yang diberikan oleh Ketua bank sampah. Tahap terakhir dari pengawasan adalah mengoreksi pekerjaan dari petugas bank sampah. Untuk mengoreksi pekerjaan dari Petugas, Ketua bank sampah akan melihat sampah yang diambil dari hasil pengumpulan sampah , dan melihat kehadiran petugas dalam setiap kegiatan.

\section{SIMPULAN DAN SARAN \\ Simpulan}

Berdasarkan hasil penelitian yang dilakukan, maka dapat ditarik kesimpulan sebagai berikut. Perencanaan di Bank Sampah "Sampat Sehe Kedas" Desa Selat sudah menunjukan perencanaan yang baik. Hal ini dilihat dari tahap awal perencanaan yaitu menentukan tujuan yang ingin membantu masyarakat Desa Selat dalam mengelola sampah rumah tangga menjadi barang yang bernilai ekonomis dan menjadikan lingkungan Desa Selat menjadi desa yang bersih. Tahap kedua yaitu dengan pembentukan organisasi, menyediaan anggaran keuangan, menyediakan tempat untuk menampung sampah, mencari nasabah dan memenuhi pelengkapan dan peralatan yang perlu digunakan untuk pelaksanaan pengambilan sampah, Tahap ketiga dari perencanaan yaitu mengidentifikasi kendala-kendala yang akan ditemui selama kegiatan bank sampah di laksanakan. Tahap terakhir dari perencanan yaitu mengembangkan rencana-rencana dengan melakukan musyawarah yang dilakukan setiap 6 bulan.

Pengorganisasian di Bank Sampah "Sampat Sehe Kedas" Desa Selat sudah berjalan dengan baik. Hal ini dapat diketahui dari segi pembentukan organisasi yaitu ada penasehat, ketua, sekertaris, bendahara, dan petugas pengambilan sampah. Setiap anggota yang ada di organisasi Bank Sampah "Sampat Sehe Kedas" Desa Selat sudah memiliki tugasnya masing-masing sesuai dengan yang disepakati oleh pengurus bank sampah, yaitu ada penasehat yang selaku penanggung jawab selama kegiatan bank sampah Bank Sampah "Sampat Sehe Kedas" Desa Selat berjalan. Ketua yang bertugas sebagai pengawas dalam setiap kegitan, sekertaris bertugas melakukan pencatakan pembukuan, bendaraha bertugas sebagai pencatatan keuangan, dan petugas yang bertugas sebagai tenaga pengambilan sampah ke nasabah Bank Sampah "Sampat Sehe Kedas" Desa Selat.

Pengarahan di Bank Sampah "Sampat Sehe Kedas" Desa Selat sudah di laksanakan dengan baik. Hal ini dapat di lihat dari tahap awal pengarahan yaitu ketua memberikan kordinasi kesetiap pengurus dan petugas sebelum melakukan kegitan, tahap kedua yaitu ketua memberikan motivasi ke pengurus dan petugas di Bank Sampah "Sampat Sehe Kedas" Desa Selat bersemangat dalam mencapai tujuannya, dan tahap terakhir yaitu komunikasi antara pengurus, petugas dan nasabah. Pengawasan di Bank Sampah "Sampat Sehe Kedas" Desa Selat sudah berjalan dengan baik. Hal ini dapat dilihat dari cara pengawasan di bank Sampah "Sampat Sehe Kedas" Desa Selat yang pertama yaitu melihat standar pelaksanaannya apakah pengurus dan petugas sudah berkerja dengan standar pelaksanaan pengambilan sampah di nasabah sudah sesuai yang di tetapkan yaitu sampah yang ditabung adalah sampah nonorganik dengan harga perkilo Rp 500,00 dan pelaksanaan kegiatan pengambilan sampah dilakukan pada hari minggu. Tahap kedua dalam pengawasan di Bank Sampah "Sampat Sehe Kedas" Desa Selat yaitu dengan mengukur kinerja apakah pengurus dan petugas bank sampah sudah berkerja dengan waktu dan hari yang sudah di tetapkan. Dan tahap ketiga yaitu mengoreksi dari pekerjaan yang sudah dilakukan oleh pengurus dan 
petugas Bank Sampah "Sampat Sehe Kedas" Desa Selat, hal ini dilakukan untuk mengetahui pekerjaan yang dilakukan oleh pengurus dan petugas apakah sudah sesuai dengan standar pelaksanaan yang ada di Bank Sampah "Sampat Sehe Kedas" Desa Selat.

\section{Saran}

Adapun saran yang bisa diberikan peneliti melalui hasil penelitian yang dilakukan di Bank Sampah "Sampat Sehe Kedas" Desa Selat, sebagai berikut. Bagi pengurus dan petugas Bank Sampah "Sampat Sehe Kedas" Desa Selat, dalam pengambilan sampah kenasabah agar dilakukan satu minggu dua kali supaya sampah yang ada di nasabah tidak menumpuk. Dan pengurus perlu juga memberikan pemahaman tentang cara mengelola sampah agar menjadi barang bernilai ekonomis kesetiap warga Desa Selat yang belum ikut kegiatan menabung sampah ke Bank Sampah "Sampat Sehe Kedas" Desa Selat supaya mendapatkan nasabah yang lebih banyak dan menciptakan lingkungan Desa Selat yang bersih bebas dari sampah dan polusi.

\section{DAFTAR PUSTAKA}

Amir. (2006). Pengantar IImu Komunikasi. Medan: Pustaka Bangsa.

Arikunto, S. (1993). Manajemen Penelitian. PT. Raja Grafindo Jakarta: Persada.

Bucher, C. A., \& Krotee, M. L. (2004). Management of physical Education and Sport. McGraw-Hill.

Burhanudin. (1994). Analisis Administrasi, Manajemen dan Kepemimpinan Pendidikan. Jakarta: Bumi Aksara.

Fattah, N. (2004). Prinsip-prinsip
Manajemen. Bandung: Bina Aksara.

Follet, M. P. (1997). Defenition of Management.

Garry K, H. (2004). Probabilita dan Statistik dalam IImu Rekayasa dan Manajemen. Jakarta: UI Press.

Hadiwiyoto, S. (1983). Penanganan dan Pemanfaatan Sampah. Jakarta: Yayasanidayu.

Michael, A. (2002). Manajemen Sumber Daya Manusia. Jakarta: PT. Gramedia Asri Media.

Miles, M. B., \& Amichael, H. (2007). Analisis Data Kualitatif Buku Sumber tentang Metode-metode Baru. Terjemahan Tjetjen Rohendi Rohisi. Universitas Indonesia.

Nasution. (2003). Metode Penelitian Naturalistik Kualitatif. bandung: Tarsito.

Siswanto. (2005). Pengantar Manajemen. Jakarta: Bumi Aksara.

Sugiyono. (2015). Metode Penelitian Pendidikan (Pendekatan Kuantitatif, Kualitatif dan R\&D). Bandung: CV. Alfabeta.

Sutarno, N. (2004). Manajemen Perpustakaan. jakarta: Media Samitra Utama.

T. Hani, H. (2000). Manajemen (2nd ed.). Yogyakarta: BPFE. 